How to cite this article:

Mohd Ariffin, M. S., Wan-Hussin, W. N., \& Abdul Malak, S. S. D. (2020). Disclosure of AGM minutes on corporate website: An assessment of Malaysian listed companies. International Journal of Banking and Finance, 15(2), 1-24. https://doi.org/10.32890/ ijbf2020.15.2.1

\title{
Disclosure of AGM Minutes on Corporate Website: An Assessment of Malaysian Listed Companies
}

\author{
${ }^{1}$ Mohd Shazwan Mohd Ariffin \\ ${ }^{2}$ Wan Nordin Wan-Hussin
}

Othman Yeop Abdullah Graduate School of Business, Universiti Utara Malaysia, Malaysia

${ }^{3}$ Siti Seri Delima Abdul Malak

Tunku Intan Safinaz School of Accountancy,

Universiti Utara Malaysia, Malaysia

${ }^{1}$ Corresponding author:mohd_shazwan1@oyagsb.uum.edu.my;

${ }^{2}$ wannordin@uum.edu.my;

3seridelima@uum.edu.my

A R T I C L E I N F O

Article history:

Received 3 March 2020

Revised 30 April 2020

Accepted 30 May 2020

Published 31 July 2020

Keywords:

AGM minutes, shareholder activism, grey directors, Malaysian, corporate website.

JEL Code: G30
A B S T R A C T

Disclosure of annual general meeting (AGM) minutes on the corporate website is considered as additional disclosure. Consequently, Listing Requirements states compulsory disclosure of corporate information. In this regard, the awareness of compulsory disclosure of information among all Malaysian listed companies in 2017 was below expectations. Despite the role of AGM minutes as documented proof of meeting, the management had been reluctant to disclose AGM minutes on the corporate website unless demanded by the shareholders. This paper focuses on previous mandatory disclosure of discussions on key matters after 


\begin{abstract}
AGM minutes among 261 listed companies based on the financial year ended December 31, 2016. The findings indicated that shareholder activism and the role of grey directors exerted influence on the disclosure of AGM minutes on the corporate website. Undoubtedly, management and investors have contributed toward voluntary disclosure in line with the government's role to enhance shareholder rights. Besides, grey directors' contribution towards information disclosure has remained relatively unexplored.
\end{abstract}

\title{
1. Introduction
}

Slack and Shrives (2010, p. 84) claimed that researchers and professionals strongly believe that the demand for voluntary disclosures by stakeholders have been increasing for the last two decades. Recently, a majority of researchers argued that there has been less effort given to papering between corporate governance and voluntary disclosures. In fact, there have not been many studies regarding AGM minutes on corporate websites even though it is acknowledged that financial reporting and disclosures are significant for a firm's performance and good governance especially towards its investors (Healy \& Palepu, 2001, p. 406).

The intention of this paper is to highlight the importance of AGM minutes on corporate websites. Even though there has been research regarding AGMs such as formalities and speeches at AGMs (Catasús \& Johed, 2007); the format of AGM minutes (Nyqvist, 2015); the way top management conducts AGMs and accesses the accounts (Carrington \& Johed, 2007) and the procedure of AGMs (Apostolides, 2010), there is still a lack of studies which focuses on the disclosure of AGM minutes on corporate websites. Thus, this study intends to explore the influence of shareholder participation and grey directors on AGM minutes displayed on corporate websites.

According to the Minority Shareholders Watch Group (MSWG), "one of the best practices which MSWG advocated over the years is the publication of Annual General Meeting (AGM) minutes on the listed issuer's website in a timely manner. It was aimed that all publicly listed companies (plc) will take the 
initiative to publish a meaningful summary of key matters arising at the AGM, which, among others, should include pertinent questions raised at the AGM and the Board's responses as well as the full attendance list of the directors at the $A G M$ " (website MSWG).

So far, studies conducted by Samaha, Khlif, and Hussainey (2015) on voluntary disclosures focused on corporate social responsibility (CSR), intellectual capital, directors' remuneration, dividend policies, forward-looking information, risk disclosures, and internet disclosures. Despite the role of AGM minutes as prima facie evidence of documentation, there is a noticeable lack of studies on the disclosure of AGM minutes on corporate websites. It is noted that an AGM can be stated as the place where all members are called to generate forums for discussions in accordance with company law which provides valuable opportunities for promoting organizational accountability (Cordery, 2005, p. 2). In other words, the AGM should be a place for members to support the closing of the accounting year (Catasús \& Johed, 2007: p. 172).

In Malaysia, AGM occurs once a year whereby company executives (top management) together with the board of directors (non-executive and independent directors) and shareholders/investors meet. The focus point of this paper is aligned with Section 143(1) of the previous Companies Act 1965 whereby all companies established in Malaysia (public or private) are required to convene its first AGM within eighteen (18) months from the date of incorporation of the company in Malaysia (Malaysia Companies Act 1965, amended 1999).

However, effective January 31,2017 , due to the transition period from the Companies Act 1965 to the new Companies Act 2016, there was a major change regarding the convening of an AGM. Beginning January 31, 2017, Section 340(1) of the Companies Act 2016 states that "every public company shall hold an AGM in every calendar year besides other meetings held during that period, to transact the following business:

a) the laying of audited financial statements and the reports of the directors and auditors;

b) the election of directors in place of those retiring;

c) the appointment and the fixing of the fee of directors; and

d) any resolution or other business of which notice is given in accordance with this Act or the Constitution."

In summary, the Companies Act 1965 stressed the importance of the AGM to be held once in every calendar year either by the circulation of resolution or physical AGM regardless whether they are public or private companies. In contrast, the Companies Act 2016 (CA 2016) only required publicly listed companies (PLCs) to hold physical AGMs once in every calendar year. This is 
no longer applicable for private companies in Malaysia (Companies Act, 2016 on Section 340(1): p. 320) ${ }^{1}$.

It is notable that the implementation of the CA 2016 is a benchmark towards good governance and applicable to all sections except Section 241 and Division 8 of Part III. Interestingly, the new Companies Act 2016 highlighted that under Section 340(3) of CA 2016, only public companies whether listed or non-listed need to convene a physical meeting within eighteen (18) months from the date of incorporation of the company in Malaysia.

With the updated Main Market Listing Requirements, the outcome of the AGM which consists of the total voting results will be made available to the public on the day the meeting is conducted. Meanwhile, for companies that applied, they are required to ensure that their corporate websites are active and accessible to the public ${ }^{2}$. In fact, the company is solely responsible in ensuring that the link to company announcements appears in its corporate website(s).

Based on the regulations, Section 343 of the CA 2016 states that AGM minutes is a formal record of proceedings at a meeting and is considered prima facie evidence. Thus through the AGM minutes, management and investors will know the list of participants during the meeting, the agenda discussed, questions raised by the audience, time frame of the meeting, total voting of resolution(s), and outcome of the meeting which can benefit existing and potential shareholders who are unable to attend or are not involved in the event as mentioned in the Best Practice Guide on AGMs for Listed Issuers published by MAICSA-Bursa Malaysia Berhad in 2016 (MAICSA, 2016).

The rest of this paper is organised as follows; Section 2 briefly presents the literature review and hypotheses development; Section 3 discusses the research methodology; Section 4 highlights the results and analysis, and Section 5 presents the conclusion and contributions of this paper.

\section{Literature Review}

Currently, there is no accepted standard guideline regarding AGM minutes even though generally there are a few formats of minutes prepared and drafted in Malaysia. Each type and format of minutes depends on specific usage where it fulfills certain objectives (Foo, 2019, p. 25). To date, the Securities Commission of Malaysia, Institutional Investor Council of Malaysia, and the Minority Shareholders Watch Group have launched the AGM Corporate Governance Checklist for Shareholders on February 5, 2020 which includes the importance of AGM minutes to enhance a better perspective of corporate governance (Securities Commission of Malaysia, 2020, p. 16).

Collectively, the AGM minutes acts as evidence of a written record and must be audited by a licensed auditor, yearly. In fact, the Chairman used 
the AGM minutes as confirmation of a true record of the previous meeting (The Malaysian Association of the Institute of Chartered Secretaries and Administrators [MAICSA], 2016). However, there is an issue regarding the need for AGM minutes to be disclosed on corporate websites which had been non-mandatory in Malaysia. The compulsory disclosure of AGM minutes on corporate websites was effected in 2016 with the amendment of the Main Market Listing Requirements Chapter 9-Continuing Disclosure Paragraph 9.21(2) (b) which stipulates that "a listed issuer must publish the following information on its website such as ...summary of the key matters discussed at the AGM, as soon as practicable after the conclusion of the AGM" (website Bursa Malaysia).

The gap in the literature is related to the reluctance of the PLCs to publish their AGM minutes on their corporate websites even though Bursa Malaysia Berhad has released a letter to the board of directors to comply with Paragraph 9.21(2) for both Main Markets and ACE Markets. This can be seen as the MSWG noted that only the top 100 listed companies published their AGM minutes on their corporate websites from 2017 onwards instead of all listed companies in Malaysia.

There has been a lot of studies which focused on the meeting process (Apostolides \& Boden, 2005; Nyqvist, 2015), implementation of corporate governance (Apostolides, 2010), conduct of meetings (Carrington \& Johed, 2007; Schwartz-Ziv \& Weisbach, 2013), and criteria on information of corporate website disclosures (Kelton \& Yang, 2008; Martherly \& Burton, 2005). However, there is a lack of studies on the disclosure of AGM minutes on corporate websites in Malaysia and other countries. The publication of AGM minutes on corporate websites can be considered as one of the new prospects in voluntarism that has been given less attention by researchers, either locally or globally.

In this paper, the voluntary disclosure is extended by examining the AGM minutes on corporate websites in Malaysian PLCs with the financial year ended December 31, 2016 and focused on companies listed under the Main Market. Apart from examining the disclosure of AGM minutes on corporate websites, this paper also addressed the impact of shareholders and grey directors' activism (through voting percentage) on such disclosures. In 2018, Bursa Malaysia made it compulsory for all Malaysian PLCs to provide a corporate website and publish key matters discussed at the AGM as soon as possible after the conclusion of the meeting (Bursa Saham, 2018, p. 2).

\subsection{Trend of AGM Minutes on Corporate Website}

Table 1 shows that 48 percent of the top 100 Malaysian PLCs published their AGM minutes in 2016 which is slightly better compared to the period from 2013 
to $2015^{3}$. It indicated the willingness of the companies to disclose AGM minutes on their corporate websites which reflected good governance (Rita \& Salleh, 2016).

Moreover, the Malaysia-ASEAN Corporate Governance Report (2015) revealed that calls by MSWG for a voluntary publication of AGM minutes on corporate websites was well received by most Malaysian PLCs. Most of the listed companies agreed to publish AGM minutes within 30 days after the conclusion of their AGM event (Malaysia-ASEAN Corporate Governance Report, 2015).

Table 1. Table Extract of Minority Shareholder Watch Group for All Top 100 Malaysian PLCs between 2012 and 2016

\begin{tabular}{|c|c|c|c|c|c|}
\hline Other Disclosure & $\begin{array}{c}2016 \\
(\%)\end{array}$ & $\begin{array}{l}2015 \\
(\%)\end{array}$ & $\begin{array}{c}2014 \\
(\%)\end{array}$ & $\begin{array}{c}2013 \\
(\%)\end{array}$ & $\begin{array}{c}2012 \\
(\%)\end{array}$ \\
\hline Companies with board charters & 94 & 97 & 80 & 70 & 38 \\
\hline Companies with code of ethics & 90 & 77 & 68 & 57 & 58 \\
\hline Companies which published AGM minutes & 48 & 37 & 26 & 7 & 1 \\
\hline Companies which published M\&A & 41 & 28 & 22 & 11 & 8 \\
\hline $\begin{array}{l}\text { Companies which disclosed individual } \\
\text { director remuneration }\end{array}$ & 43 & 33 & 35 & 39 & 34 \\
\hline Companies with dividend policies & 41 & 38 & 35 & 38 & 34 \\
\hline Companies with whistle blowing policies & 86 & 70 & 51 & 48 & 42 \\
\hline $\begin{array}{l}\text { Companies with corporate responsibility } \\
\text { policies }\end{array}$ & 94 & 93 & 97 & 94 & 90 \\
\hline $\begin{array}{l}\text { Companies which disclosed training } \\
\text { attended by each of its directors }\end{array}$ & 80 & 65 & 59 & 65 & 56 \\
\hline $\begin{array}{l}\text { Annual financial report released within } \\
\text { four months }\end{array}$ & 99 & 99 & 82 & 81 & 81 \\
\hline
\end{tabular}

*Source: Minority Shareholder Watch Group Media Release (2016).

In comparison, Table 2 reported specific AGM minutes disclosed on corporate websites before and after the implementation of the CA 2016. The table indicated that there was an increase in disclosures of AGM minutes from 
nine percent (2016) to 37 percent (2017). The huge jump in percentage was due to initiatives enforced by the regulatory bodies that required all listed companies either the top 100 Malaysian PLCs or non-top 100 Malaysian PLCs to publish their AGM minutes or key matters on their corporate websites as soon as possible after their meetings.

In accordance with the CA 2016, which began in 2017, several voluntary disclosure items such as the establishment of dividend policies, whistle blowing policies, implementation of corporate responsibility policies, disclosure of training attended by individual directors, and the release of annual financial reports (FY) within four months became either not available or mandatory as stipulated by the Bursa Malaysia Listing Requirements.

Table 2. Table Extract of Minority Shareholder Watch Group for All Listed Companies between 2016 and 2017

\begin{tabular}{lcc}
\hline \multicolumn{1}{c}{ Other Disclosure } & $2017(\%)^{*}$ & $2016(\%)$ \\
\hline Companies with board charters & 86 & 82 \\
Companies with code of ethics & 60 & 57 \\
Companies which published AGM Minutes & 37 & 9 \\
Companies which published M\&A & $\mathrm{n} / \mathrm{a}$ & $\mathrm{n} / \mathrm{a}$ \\
Companies which disclosed individual director remuneration & 11 & 10 \\
Companies with dividend policies & $\mathrm{n} / \mathrm{a}$ & $\mathrm{n} / \mathrm{a}$ \\
Companies with whistle blowing policies & $\mathrm{n} / \mathrm{a}$ & $\mathrm{n} / \mathrm{a}$ \\
$\begin{array}{l}\text { Companies with corporate responsibility policies } \\
\text { Companies which disclosed training attended by each of its } \\
\text { directors }\end{array}$ & $\mathrm{n} / \mathrm{a}$ & $\mathrm{n} / \mathrm{a}$ \\
$\begin{array}{l}\text { Annual financial report released within 4 months } \\
\text { Source: }\end{array}$ & $\mathrm{n} / \mathrm{a}$ & $\mathrm{n} / \mathrm{a}$ \\
\hline
\end{tabular}

*Source: Malaysia-ASEAN CG Report (2017). Note: (*) n/a represents not available.

Previous studies described shareholder activism as how shareholders exert influence by way of their involvement and engagement with company management through monitoring and control mechanisms based on governance 
structure (Akmal Musa \& Ismail, 2016; Gillan \& Starks, 2000). Empirical evidence has divided shareholder activism into public pension funds, coordinated groups of investors, and individual investors (Gillan \& Starks, 2000, p. $277-$ 278).

To reiterate, the need for active participants especially in corporate policy has affected managers' interests. In a study involving 130 active investors of firms from the United States of America showed that managers tend to react toward activism based on disclosure information (Bourveau \& Schoenfeld, 2017, p. 30). As such, passive shareholders focused on additional disclosures tend to vote against resolutions if a firm does not fulfill their preferences (Bourveau \& Schoenfeld, 2017: p. 3).

On the other hand, activist shareholders are more likely to become proactive for the sake of their investors. The manager is aware that once the company increases its vulnerability, there is more susceptibility in terms of exposure to activism (Klein \& Zur, 2009, 2011). Unfortunately, even though shareholder activism by institutional investors has been increasingly prominent over the last few years, studies which investigate the effects of such activism towards voluntary disclosures are relatively limited (Gillan \& Starks., 2000).

In accordance with De Jong, Mertens and Roosenboom (2006). Shareholders' voting at general meet and Roosenboom (2006), shareholder activism during a meeting on dominant shares tends to influence agency cost and maximize shareholders' wealth. This paper can contribute to the literature as not many studies are focused on the emergence of shareholder activism (voting percentage) especially in terms of the numbers in favor or against the resolution for voluntary disclosure of AGM minutes on corporate websites.

\subsection{Issue with Shareholder Activism}

Van der Elst (2012) studied whether there was a relationship between shareholder rights and shareholder activism in annual general meetings. The result of a comparison among five countries showed no significant relationship between the number of items or the importance of items to be voted at general meetings and the attendance of shareholders. However, it was highlighted that shareholders have the power to attend and support items in the agenda during AGMs. There is also the issue of free-riding or apathetic shareholders during AGMs which suggests the need for a more in-depth analysis regarding shareholder activism (Van der Elst, 2012, p. 63).

Bourveau and Schoenfeld, (2017) who studied the relationship between voluntary disclosure and shareholder activism suggested that, broadly, shareholder activism plays a crucial determining role in voluntary disclosures. The evidence also suggests that managers are more receptive to disclosures once shareholders are active in their firm. 
Van der Elst (2012) identified shareholders as the owners of the company. In essence, shareholders are the supreme and final decision makers of the company even though they only own company shares and not the company management. Currently, the power of shareholders is only limited to voting on issues governed by the law or to allocate decision-making power in the general meeting. This limitation of power leads to active participation and the tendency to vote for or against resolutions at general meetings namely, through having share vote percentage (Van der Elst, 2012, p. 40-41).

Previous studies on Malaysian companies in 2001-2002 regarding the impact of family-controlled companies and board composition towards corporate transparency indicated that companies with more affiliated directors brought significant changes to corporate disclosures (Wan-Hussin, 2009).

Generally, majority shareholders tend to dominate the decision-making process instead of minority shareholders (Catasús \& Johed, 2007, p. 178). This is because other than attending general meetings, shareholders also exercise their power through voting resolution (voting percentage). Traditionally, in Malaysia, most of the dominant voting process was either by a show of hands or by poll

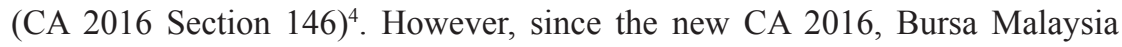
requires all resolutions in general meetings to be voted by poll. The proposal to exercise voting by poll is also recommended by the latest Malaysian Code on Corporate Governance (MCCG 2017-Practice 12.3).

Does share voting influence the decision to disclose AGM minutes on corporate websites? As mentioned earlier, AGM minutes on corporate websites are still relatively new in Malaysia. However, in the United Kingdom, it has already established the United Kingdom Code of Corporate Governance as “... when, in the opinion of the board, a significant proportion of votes have been cast against a resolution at any general meeting, the company should explain when announcing the results of voting what actions it intends to take to understand the reasons behind the vote result..." (Council, 2012).

Therefore, the importance of the number of votes (voting percentage) whether in favor or against the resolution can have a significant impact on the disclosure of AGM minutes on corporate websites. Based on the statement, it is predicted that shareholder participation can influence the disclosure of AGM minutes on corporate websites.

Thus, the following hypothesis is posited:

$H_{1}$ : There is a positive relationship between shareholder participation and disclosure of AGM minutes on corporate websites.

\subsection{Emerging Grey Directorship}

Previous studies showed that the function of grey directors is mainly to receive less attention compared to other directors. The agency theory suggests that 
agency conflicts happen due to the separation of ownership and control in a firm. Through this theory, the directors bear responsibility for the company's future value in disseminating private information to the public (Jensen \& Meckling, 1976).

Grey directors can be defined as directors that have social ties with company management such as a former director, possess shares in the company, and provide beyond monitoring and advisory functions of the boardroom (Hsu \& Wu, 2014). According to Baysinger and Butler (1985), grey directors comprise a mixture of executive and independent directors who provide proper administrative and multiple tasks (as cited in $\mathrm{Hsu} \& \mathrm{Wu}, 2014$ ). It is also reported that companies with a large proportion of grey directors in the board composition can hinder corporate failures such as in the United Kingdom (Hsu $\& \mathrm{Wu}, 2014)$.

Borokhovich, Boulton, Brunarski and Harman (2014) found that grey directors with shares in a company could jeopardise their position as directors of the company. Based on a sample from 370 top executives and board chairs from 1978 to 2007, Borokhovich et al. (2014) noted that a firm's succession plan is influenced by the power of grey directors. The results also revealed that grey directors' ownership helps to align company interest with that of the shareholders.

To date, it has been debated based on empirical evidence whether the grey director tends to act as advisor instead of monitoring the boardroom (Vicknair, Hickman \& Carnes, 1993). Unlike executive or independent directors, the grey director plays a crucial role as independent advisor and decision maker of the company.

Thus, it is posited that grey directors could affect management strategy in voluntary disclosure. A paper by Ibrahim and Angelidis (1995) revealed that outside directors (which include grey directors) tend to influence company performance because of their strong mutual relationship with the stakeholders as these directors know their expectations and are able to entertain investors' demands. The result of the paper indicated that outside directors provide greater corporate responsibility but a weaker orientation towards the economic performance of companies. It is predicted that grey directors can influence the disclosure of AGM minutes on corporate websites.

Hence, the second hypothesis is as follows:

$H_{2}$ : There is a positive relationship between grey directors and disclosure of AGM minutes on corporate websites.

\section{Methodology}

In this paper, we selected companies that have annual reports made publicly available in their corporate websites and the Bursa Malaysia website. We chose 
2016 as the financial year ended for our sample because the preferred year ended by the PLCs is either in June or December. Hence, on January 31, 2017, the implementation of the new CA 2016 superseded the previous acts together with the latest Malaysian Code on Corporate Governance (MCCG, 2017) in April 2017 and enhancement of the Bursa Malaysia Securities Berhad Listing Requirements subsequent to the release of the MCCG (Corporate Governance Guide 3, 2017).

The initial sample was 274 companies. We excluded 13 companies due to missing data or unfulfilled criteria. The final sample with the required data was 261 companies listed under the Main Market of the Bursa Malaysia website. Apart from collecting annual reports, notices of annual general meetings, outcomes of general meetings and corporate governance (CG) reports, we also collected board profiles, company profiles and other data from the Bloomberg database, Thomson Reuters DataStream database and respective corporate websites.

As mentioned earlier, this paper was conducted based on companies listed in the Main Market of Bursa Malaysia for the financial year ended December 31, 2016. This paper also applied secondary data as the main data collection. The information on company characteristics and directors' profiles were collected, coded and extracted from annual reports published under bursa announcements. In addition, the disclosure of AGM minutes on the corporate website was downloaded, analyzed and extracted from each company's corporate website.

\subsection{Measurement of Variables}

The measurement of variables in this paper, adopted from studies by Kassim, Ishak, and Manaf (2013, p. 322) were proxies based on company characteristics and directors' profiles namely market sector, business activity, directors' profiles and related governance information.

The ASEAN CG Scorecard served as a benchmark because it provides details and rigorous methodology against international best practices to assess corporate governance performance among ASEAN countries consisting of Malaysia, Indonesia, Singapore, Thailand, Vietnam, and the Philippines. The scorecard helps investors and public issuers to compare and contrast their corporate information for a transparent investment decision-making process. Besides, according to the ASEAN Corporate Governance Scorecard Country Reports and Assessments from 2011 to 2014, it encourages foreign direct investments among the six participating ASEAN member countries.

\subsection{Definition of Each Variable}

\subsubsection{Dependent variable-AGM minutes on corporate website}

A detailed scoring index of this paper was adopted from the checklist used by Haniffa and Cooke (2005) with minor changes to fit the context of Malaysian 
PLCs. A level disclosure of AGM minutes was collected by observing each Malaysian publicly listed corporate website under the column: "corporate governance", "media release", "investor relations" or its related section(s) to identify whether the companies published their AGM minutes or not. Besides, we also emailed to each firm that did not publish its AGM minutes to confirm the non-disclosure of AGM minutes on its corporate website. The dependent variable, $V D$ of this paper is the level of voluntary disclosure of AGM minutes measured by score ( 0 ) if there is no disclosure of AGM minutes on the corporate website and score (1) for otherwise.

\subsubsection{Independent variable-Shareholder activism}

For the independent variables in this paper, data were collected from annual reports of each corporate website, CG reports, Bloomberg database and Thomson Reuters DataStream database of the sampled firms.

With regard to shareholder participation, our paper indicated participation by measuring the resolution with share votes (unit) against the agenda of the meeting divided by the total number of shares (unit). Percentage share votes against the resolution indicate the visibility of shareholder activism during the AGM event. Therefore, shareholder participation, $S A \_$vote $\%$ in this paper was measured by way of share voting which was calculated with share votes (unit) divided by the total number of shares (unit). Share votes (unit) was measured based on the outcome of the meeting from the Bursa Announcement by identifying the higher total number of votes for and against each resolution (shareholder participation ratio at AGM). Meanwhile, the total number of shares (unit) was collected from the total number of the issued share capital of the companies as per financial year ended December 31, 2016. Shareholder participation, SA vote $(\%)=$ share votes (unit)/ total number of shares (unit)*100.

\subsubsection{Independent variable-Grey directors}

The second independent variable was the grey director. The details of the measurement for a firm assigned with grey directors, $B O D \_$grey $\%$ was measured by classification: "executive" represented the position as executive director of the company; "independent non-executive" represented the position as an independent non-executive director of the company and "grey" to represent the position as grey director/non-independent non-executive director of the company. For directors with $B O D \_$grey $\%$, by using the scoring index, the total number of grey directors of each firm was combined, recorded and coded by the total number of grey directors in each firm. 


\subsubsection{Control variable-Board size}

According to Kassim et al. (2013), previous studies had shown that large companies preferred to establish various diversifications in business such as Sime Darby Group of Companies, FGV Group of Companies (formerly known as Felda Global Ventures Group of Companies), KPJ Group of Companies and Genting Group of Companies. Theoretically, large size companies, require large capital injection which leads to the diversity of its investors, BODsize. Therefore, the role of the board of directors such as executive, non-executive or grey director with a single tier or two-tier leadership could influence disclosure of the AGM minutes on the corporate website. A large size company requires a large boardroom to control and monitor the performance of the company. Hence, a mixture of board diversity and position could provide better decision-making.

From a negative perspective, it is argued that the large number in board size could create chaos and a tendency for personal benefit instead of fulfilling company objectives. From a positive perspective, diversity in the board of directors such as the presence of independent non-executive directors could help the management and owners (investors) to aim for profit maximization. This is because independent non-executive directors work for the company and provide checks and balances in decision-making. Besides that, the more independent the directors the more voluntary information disclosed by the company. Due to this reason, BODsize is expected to influence voluntary disclosure of AGM minutes.

\subsection{Empirical Models}

The following model was developed to achieve the research objectives used to examine the disclosure of annual general meeting on the corporate website:

$$
\mathrm{VD}=\alpha_{0}+\beta_{1 \text { SA_vote } \%}+\beta_{2 \text { BOD_grey } \%}+\beta_{3 \text { BODsize }}+\mathbf{E}_{\mathrm{i}}
$$

Where, $V D$ means voluntary disclosure of AGM minutes on the corporate website, independent variables represented by BOD grey $\%$ to indicate grey directors, $S A$ vote $\%$ to denote shareholder participation and BODsize to mean board size. Details of the operational definitions of the variables, measurements and sources are shown in Table 3 . 
Table 3. Operational Definition of each Variable of the Study

\begin{tabular}{|c|c|c|c|c|}
\hline Variable(s) & Proxy & Indicator & Measurement & Source \\
\hline VD & $\begin{array}{l}\text { Disclosure } \\
\text { of AGM } \\
\text { minutes on } \\
\text { corporate } \\
\text { website }\end{array}$ & $d v$ & $\begin{array}{l}\text { indicate voluntary } \\
\text { disclosure index } \\
\text { (1=disclose } \\
\text { AGM minutes on } \\
\text { corporate website, } \\
\text { and } 0=\text { otherwise })\end{array}$ & $\begin{array}{c}\text { Corporate } \\
\text { website }\end{array}$ \\
\hline SA_vote $\%$ & $\begin{array}{l}\text { Shareholders' } \\
\text { activism } \\
\text { through } \\
\text { voting } \\
\text { percentage }\end{array}$ & $i v$ & $\begin{array}{l}\text { share votes (unit)/ } \\
\text { total number of } \\
\text { shares (unit)*100 }\end{array}$ & $\begin{array}{l}\text { Annual } \\
\text { report, Bursa } \\
\text { outcome, } \\
\text { Corporate } \\
\text { website }\end{array}$ \\
\hline $\begin{array}{l}\text { BOD } \\
\text { grey } \%\end{array}$ & Grey director & $i v$ & 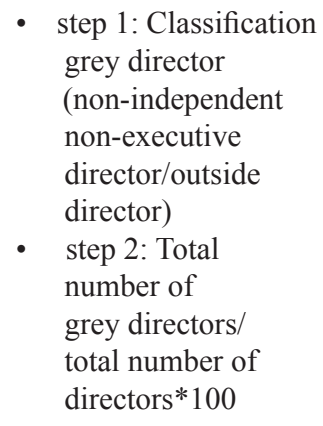 & $\begin{array}{c}\text { Annual } \\
\text { report, } \\
\text { DataStream, } \\
\text { Bloomberg }\end{array}$ \\
\hline BODsize & Board size & $c v$ & $\begin{array}{l}\text { indicated based on } \\
\text { the total number of } \\
\text { directors for each } \\
\text { firm }\end{array}$ & $\begin{array}{c}\text { Annual } \\
\text { report, } \\
\text { DataStream, } \\
\text { Bloomberg }\end{array}$ \\
\hline
\end{tabular}

Indicator(s): $\mathrm{dv}$ denotes dependent variable, iv denotes independent variable and $\mathrm{cv}$ denotes control variable of the study.

\section{Analysis of Results}

This section reports on the general findings, from descriptive statistics followed by Pearson partial correlation, one-sample t-test and regression results. It also aims to show the relationship between the dependent and independent variables in the study. The results confirm the two hypotheses posited. The data is analyzed based on the methodology described earlier.

This chapter reported the findings with discussions and suggestions for future research. This chapter arranged with a summary of general findings, 
future research recommendations and the conclusion. The result will be analysed based on the three research questions (RQs) and research objective (ROs) using SPSS software. The chapter aims to shows the association between dependent variables and independent variables. The data acquired will be analysed based on the methodology explained in earlier chapters.

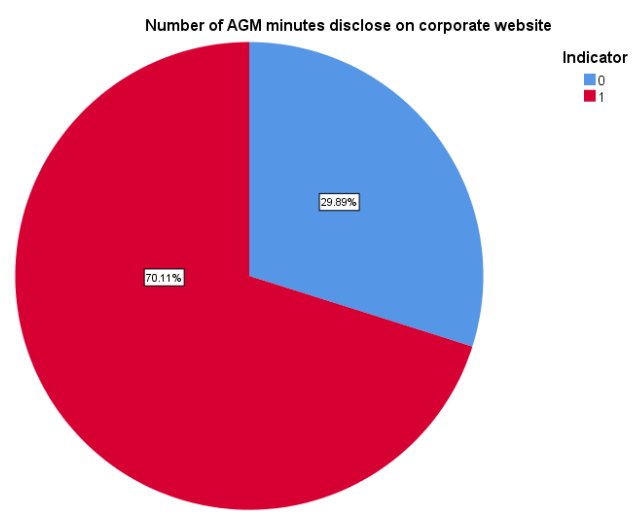

Figure 1. Distribution of AGM minutes on corporate website among Malaysian public listed companies.

From Figure 1, based on 261 companies listed under the Main Market of Bursa Malaysia, it was found that 78 companies (29.89\%) did not publish AGM minutes on the corporate website (indicated by "0") whereas 183 companies (70.11\%) disclosed the AGM minutes on the corporate website (indicated by "1"). The willingness of the listed companies to publish AGM minutes on the corporate website reflected their alignment with the initiatives of the MSWG to promote good governance through transparency and accountability ${ }^{5}$.

Table 4. Descriptive Statistics on AGM Minutes on Corporate Websites, Grey Directors, Shareholder Activism and Board Size.

\begin{tabular}{lcccc}
\hline & Minimum & Maximum & Mean & Std. Deviation \\
\cline { 2 - 5 } VD & 0.00 & 1.00 & 0.70 & 0.45 \\
SA_vote\% & 2.76 & 99.66 & 58.95 & 20.53 \\
BOD_grey\% & 0.00 & 60.00 & 19.56 & 16.63 \\
BOD size & 4.00 & 15.00 & 7.51 & 1.85 \\
\hline
\end{tabular}


From Table 4, based on the sample of 261 companies, grey directors were in the range of 0 to 60 percent per company, with a mean of 19.56 and a standard deviation of 16.63. Share vote percentage ranged from 2.76 percent to 99.66 percent with a mean of 58.95 and a standard deviation of 20.53. Board size, ranged from 4 to 15 directors, with a mean of 7.51 and a standard deviation of 1.85 .

Interestingly, there were several companies with more than half of its composition dominated by grey directors. Even though there were companies with no grey directors from the table, surprisingly there were companies with more than eight grey directors such as Bintulu Port Holdings Berhad and PBA Holdings Berhad. The awareness of the role played by grey directors concurred with results by Abdulmalik, Ahmad and Aliyu (2015) in that the proportion of grey directors in the boardroom was significantly and positively related to accrual and real earnings management compared to independent directors. This result also supported the argument that the existence of grey directors could influence disclosure of AGM minutes which was seldom explored by previous researchers.

Meanwhile, for shareholder participation via proxies by shareholder vote percentage at AGM events, the results showed that the minimum was 2.76 percent and the maximum was 99.66 percent in terms of shareholders exercising their voting rights. Therefore, Frontken Berhad had a lower shareholder vote whereas BIMB Berhad, MMC Corporation Berhad, OSK Holdings Berhad, Classic Scenic Berhad, Petronas Gas Berhad, and SP Setia Berhad had higher shareholder votes during AGM events. This reflected the assertiveness of the shareholders as to how the management should utilize their shareholdings for profit maximization. The active participation of the shareholders or by way of the presence of a corporate representative (proxy) was in accordance with the MCCG 2017 in encouraging more shareholders' attendance during AGM events.

Overall, for board size, public listed companies have a board size range of four to 15 directors. For instance, PBA Holdings Berhad has 15 directors comprising nine grey directors and six independent non-executive directors wholly owned by the state government. The composition of board size acts as a control variable that may influence disclosure of AGM minutes on the corporate website among Malaysian PLCs. The main reason is because having a mixture of directors of different characteristics, work experiences and level of education could lead to more willingness to disclose AGM minutes on corporate websites as encouraged by MSWG and Bursa Malaysia.

Accordingly, Table 5 of the partial correlation shows the dependent variable, VD; independent variables, SA_vote $\%$ and $\mathrm{BOD}$ _grey $\%$ and the control variable, BODsize. Both the two independent variables produced a strong 
correlation of $0.206^{* *}$ and $0.211^{* *}$, respectively (significant 2-tailed). In fact, the control variable also provided a good correlation with $0.124 *$ (significant 2-tailed) in this paper.

Table 5. Pearson Partial Correlation

\begin{tabular}{lllll}
\hline Variable & VD & SA_vote $\%$ & BOD_grey $\%$ & BODsize \\
\hline VD & 1.00 & & & \\
SA_vote $\%$ & $0.206^{* *}$ & 1.00 & & \\
BOD_grey $\%$ & $0.211^{* *}$ & $0.261^{* *}$ & 1.00 & \\
BODsize & $0.124^{*}$ & $0.343^{* *}$ & $0.260^{* *}$ & 1.00 \\
\hline
\end{tabular}

Notes: ** indicated the significant at the 0.05 level (2-tailed).

Tables 6 shows the results based on one-sample t-test. The one-sample t-test was used to confirm the assumption that the dependent variables, VD01 were measured either at internal or ratio level, that the data were independent and not related, with no significant outliers and that the dependent variables should be normally distributed. Thus, there was a significant difference in the mean (VD, SA_vote\%, BOD_grey\% and BOD size) between the sample and overall population and that the average mean for VD was 0.70 , SA_vote $\%$ was 58.95, BOD_grey\% was 19.56 and BODsize was 7.51 compared to the overall population average.

Table 6. One-sample T-test

\begin{tabular}{lllll}
\hline & t-value & Mean & \multicolumn{2}{c}{$\begin{array}{c}\text { 95 Confidence Interval of the Difference } \\
\text { Lower }\end{array}$} \\
& & & Upper \\
\hline VD01 & 24.698 & 0.701 & 0.650 & 0.760 \\
SA_VOTE\% & 46.385 & 58.954 & 56.452 & 61.457 \\
BOD_GREY\% & 18.992 & 19.560 & 17.532 & 21.588 \\
BODSIZE & 65.494 & 7.506 & 7.280 & 7.730 \\
\hline
\end{tabular}

Based on Table 7, the R Square of the paper was 0.007 and the adjusted R square was 0.059 which was slightly low due to minimum variables tested in this paper. The multiple regression showed that while disclosure of AGM minutes on corporate website was constant, VD, both the independent variables, SA vote $\%$ and BOD_grey $\%$ produced highly significant results, 0.002 and 0.001 , 
respectively. These results supported $H_{1}$ and $H_{2}$ that inside forces (such as grey directors) do influence the disclosure of AGM minutes on corporate websites and outside forces (such as shareholder participation during AGM) also provided significant impact on the disclosure of AGM minutes on corporate websites. However, the control variable, BODsize did not have a significant impact on the relationship with VD01, SA_vote\%, and BODgrey $\%$. Thus BODsize did not influence the disclosure of AGM minutes on corporate websites.

Table 7. Regression Results of Study

\begin{tabular}{lccccc}
\hline & $\begin{array}{c}\text { Unstandardized } \\
\text { Coefficients B }\end{array}$ & $\begin{array}{c}\text { Std. } \\
\text { Error }\end{array}$ & $\begin{array}{c}\text { Standardized } \\
\text { Coefficients } \\
\text { Beta }\end{array}$ & $\begin{array}{c}\mathrm{t}- \\
\text { statistics }\end{array}$ & Sig. \\
\hline (Constant) & & & & 2.896 & 0.004 \\
SA_vote\% & 0.003 & 0.001 & 0.153 & 2.343 & 0.020 \\
BOD_grey\% & 0.005 & 0.002 & 0.164 & 2.582 & 0.010 \\
BOD size & 0.007 & 0.016 & 0.029 & 0.451 & 0.653 \\
Adjusted R ${ }^{2}$ & 0.059 & & & & \\
F ratio & 6.41 & & & & \\
Significance & 0.00 & & & & \\
\hline
\end{tabular}

Based on the results in Section 4, preliminary analyses were conducted to ensure no violation of the assumptions of normality, linearity, multicollinearity and homoscedasticity. R Square value was 1 percent of the variance by including board size as a control variable which was relatively low. The statistically significant contribution, was indicated by the Sig. F change value for the line (.000). In addition, the ANOVA table indicated that the model was significant $(F(261)=6.41<.001)$. Meanwhile, the Coefficients table, showed that the Sig. Column, three variables, SA_vote $\%($ beta $=0.15), S A \_v o t e \%($ beta $=0.16)$ and $B O D$ size $($ beta $=003)$ made a unique contribution towards voluntary disclosure of AGM minutes on corporate websites. As shown, control measures were statistically non-significant, with grey directors recording a higher beta value followed by shareholder participation and board size.

The pivotal role of shareholder participation towards voluntary disclosure concurred with De Jong et al. (2006) in that shareholders become proactive in exercising their rights as company owners. In addition, as mentioned by Bourveau and Schoenfeld (2017), the more shareholders utilize their voting rights, the more it may affect the voluntary disclosure information, in this case, the AGM minutes on corporate websites.

Despite the few studies on grey directors, Hsu and Wu (2014) stressed that grey directors are also part of the directorship of companies. By playing 
their role as outsider directors, grey directors are free from the management of companies and therefore are able to influence company decisions as suggested by Angelidis and Ibrahim (1995). The role of grey directors should be measured in a broader perspective as grey directors serve not only to fit the composition of directorship but they can also influence board directorship in aligning shareholder demands and needs.

Thus,
$H_{1} \quad$ There is a positive relationship between shareholder Accepted participation and disclosure of AGM minutes on corporate websites.
$\mathrm{H}_{2} \quad$ There is a positive relationship between grey directors and Accepted disclosure of AGM minutes on corporate websites.

\section{Conclusion}

In a nutshell, this paper examined the relationship between voluntary disclosures of AGM minutes on the corporate website based on a sample of Malaysian public listed companies for the financial year ended December 31, 2016. It revealed that disclosures in AGM minutes in 2016 were relatively low, at 47 percent compared to other disclosures from all listed companies. This suggests that several factors may have influenced the willingness of company management to disclose their AGM minutes on the corporate website.

There are several noteworthy contributions in this paper. To the best of our knowledge, this paper is the first to highlight the importance of voluntary disclosure of AGM minutes on the corporate website. Next, this paper has also examined the link between shareholder proxies (by way of shareholder participation voting at AGM events) and grey directors on the disclosure of AGM minutes on the corporate website.

Besides, this paper offers some insights on shareholder participation and grey directors using data from a developing country, Malaysia. This paper in particular, complemented previous research which emphasized the importance of grey directors in influencing voluntary disclosures.

This paper also noted that meaningful disclosure of AGM minutes on the corporate website in Malaysia was relatively low in 2016 during the period of study. Subsequently, the new Companies Act followed by the Malaysian Code on Corporate Governance and the Corporate Governance Guide 3 came into effect in 2017. Eventually based on the Minority Shareholder Watch Group media released in 2017, almost 78 percent of the top 100 PLCs disclosed their 
AGM minutes on the corporate website. The disclosures were aligned with Bursa Malaysia requirements in Paragraph 9.21(2) (b) on the disclosure of AGM key matters after a meeting is held.

The findings showed that grey directors and shareholder activism (voting percentage) did influence the level of AGM minutes of the disclosure. The results supported the government initiatives in introducing the Malaysian Code for Institutional Investors 2014. As such, this paper has emphasized the importance of grey directors and shareholders which are relatively unexplored. Future studies should be conducted on extensive factors which lead to the disclosure of AGM minutes on the corporate website as the way forward in promoting good corporate governance.

\section{Acknowledgements}

The authors would like to thank the staff of the Minority Shareholders Watch Group for the necessary support and assistance. We would also like to thank the Editor and independent reviewers of the International Journal of Banking and Finance for their constructive comments and suggestions.

\section{Endnotes}

1 Malaysia Companies Act 2016. Retrieved from https://www.ssm.com.my/ Pages/ Legal_Framework/Document/Act\%20777\%20Reprint.pdf (Section 340(2) on Annual general meeting).

2 Fullarticle. Retrieved from https:/www.bursamalaysia.comsites/5bb54b e15f36ca0af339077a/assets/5c10c71ef67d7c7c0037bfc7/ICN_1_2018. pdf (Issuers Communication Corporate Website for Listed Issuers (ICN 1/2018).

3 Minority shareholder watch group or MSWG was established in 2000 as one of the government's initiative to protect the interests of minority shareholders through shareholder activism by encouraging good governance amongst public listed companies with the objective of raising shareholder value over time.

4 Section 332(1) of the CA 2016 and Paragraph 8.29A(1) of the Bursa Malaysia Listing Requirements stated that any resolution by plc laid in the notice of AGM must be voted by poll.

5 On July 18, 2018, Bursa Malaysia Berhad released a letter to the board of directors (listed issuers/corporations) on Compliance with Paragraph/Rule 9.21 of the Main/ACE Market Listing Requirements. 


\section{References}

Abdulmalik, S., Ahmad, A. C., \& Aliyu, U. B. (2015). Financial reporting quality: The role of independent and grey directors, board continuous training and internal audit function. IPBJ, 7(2), 40-57.

Akmal Musa, M., \& Ismail, S. E. (2016). Shareholder activism, institutional shareholders and agency problems in Malaysia. Global Journal of Business and Social Science Review, 4(3), 30-36.

Apostolides, N. (2010). Exercising corporate governance at the annual general meeting. Corporate Governance: The International Journal of Business in Society, 10(2), 140-149.

Apostolides, N., \& Boden, R. (2005). Cedric the Pig: Annual General Meetings and Corporate Governance in the UK. Social Responsibility Journal, 1(1/2), 53-62.

Bank, A. D. (2016). ASEAN Corporate Governance Scorecard Country Report and Assesment 2014.

Baysinger, B. D., \& Butler, H. N. (1985). Corporate governance and the board of directors: Performance effects of changes in board composition. Journal of Law, Economics \& Organization, 1(1), 101-124.

Borokhovich, K. A., Boulton, T. J., Brunarski, K. R., \& Harman, Y. S. (2014). The incentives of grey directors: Evidence from unexpected executive and board chair turnover. Journal of Corporate Finance, 28, 102-115.

Bourveau, T., \& Schoenfeld, J. (2017). Shareholder activism and voluntary disclosure. Review of Accounting Studies, 22(3), 1307-1339.

Carrington, T., \& Johed, G. (2007). The construction of top management as a good steward: A paper of Swedish annual general meetings. Accounting, Auditing \& Accountability Journal, 20(5), 702-728.

Catasús, B., \& Johed, G. (2007). Annual general meetings — rituals of closure or ideal speech situations? A dual analysis. Scandinavian Journal of Management, 23(2), 168-190.

Cordery, C. J. (2005). The Annual General Meeting as an accountability mechanism. Retrieved from https://papers.ssrn.com/sol3/papers. cfm?abstract_id=1286930

Corporate Governance Guide 3 (2017). Retrieved from https://bursasustain. bursamalaysia.com/dropletdetails/resources/corporate- g o v e r n a n c e guide.

Council, F. R. (2012). The UK corporate governance code. London, September.

De Jong, A., Mertens, G., \& Roosenboom, P. (2006). Shareholders' voting at general meetings: Evidence from the Netherlands. Journal of Management and Governance, 10(4), 353-380. 
Foo, K. P. K. (2019). Corporate Voice-Minutes of Meetings Part 2, 25.Retrieved from http://maicsa.org.my/interactive/ejournal/ejournal. aspx? ejournal=1810.

Gillan, S. L., \& Starks, L. T. (2000). Corporate governance proposals and shareholder activism: The role of institutional investors. Journal of Financial Economics, 57(2), 275-305.

Haniffa, R. M., \& Cooke, T. E. (2005). The impact of culture and governance on corporate social reporting. Journal of Accounting and Public Policy, 24(5), 391-430.

Healy, P. M., \& Palepu, K. G. (2001). Information asymmetry, corporate disclosure, and the capital markets: A review of the empirical disclosure literature. Journal of Accounting and Economics, 31(1-3), 405-440.

Hsu, H. H., \& Wu, C. Y. H. (2014). Board composition, grey directors and corporate failure in the UK. The British Accounting Review, 46(3), 215227.

Ibrahim, N. A., \& Angelidis, J. P. (1995). The corporate social responsiveness orientation of board members: Are there differences between inside and outside directors? Journal of Business Ethics, 14, 405-410.

Jensen, M. C., \& Meckling, W. H. (1976). Theory of the firm: Managerial. Journal of Financial Economics, 3, 305-360.

Kassim, A. A. M., Ishak, Z., \& Manaf, N. A. A. (2013). Board effectiveness and company performance: Assessing the mediating role of capital structure decisions. International Journal of Business and Society, 14(2), 319.

Kelton, A. S., \& Yang, Y. W. (2008). The impact of corporate governance on Internet financial reporting. Journal of Accounting and Public Policy, 27(1), 62-87.

Klein, A., \& Zur, E. (2009). Entrepreneurial shareholder activism: Hedge funds and other private investors. The Journal of Finance, 64(1), 187-229.

Klein, A., \& Zur, E. (2011). The impact of hedge fund activism on the target firm's existing bondholders. The Review of Financial Studies, 24(5), 1735-1771.

Malaysian Association of the Institute of Chartered Secretaries and Administrators MAICSA. (2016). Best practice guide on AGMs for listed issuers. Retrieved from http://www.maicsa.org.my/ download/publication/ publication_agm.pdf.

Main Market and ACE Market on Issuers Communication Corporate Website for Listed Issuers (ICN 1/2018). Retrieved from http://www. bursamalaysia.com/misc/system/assets/25717/ICN_1_2018\%20-\%20 Guidanceon CorporateWebsiteDisclosure.pdf.

Main Market Listing Requirement (2016). 
Malaysia Companies Act. (1965, amended 1999). Kuala Lumpur: International Law Book Services.

Malaysia Companies Act. (2016). Kuala Lumpur: International Law Book Services.

Malaysia-ASEAN Corporate Governance Report (2015). Retrieved from https:// www.mswg.org.my/sites/default/files/MSWG_2015_ASEANCG SCORECARD_Web_version_0.pdf.

Matherly, C. M., \& Burton, H. A. (2005). An analysis of corporate website disclosures. Management Accounting Quarterly, 6(2), 26.

Mort, S. (1991). The minutes - A guide for company secretaries and managers. England: Brookfield.

Nyqvist, A. (2015). The corporation performed: Minutes from the rituals of annual general meetings. Journal of Organizational Ethnography, 4(3), 41-355.

Poulsen, T., Strand, T., \& Thomsen, S. (2010). Voting power and shareholder activism: A paper of Swedish shareholder meetings. Corporate Governance: An International Review, 18(4), 329-343.

Rita, B., \& Salleh, H. (2016). Report of AGM Practices by Malaysian Companies. Malaysia-ASEAN CG Report 2015. Kuala Lumpur, Malaysia.

Samaha, K., Khlif, H., \& Hussainey, K. (2015). The impact of board and audit committee characteristics on voluntary disclosure: A metaanalysis. Journal of International Accounting, Auditing and axation, 24, 13-28.

Schwartz-Ziv, M., \& Weisbach, M. S. (2013). What do boards really do? Evidence from minutes of board meetings. Journal of Financial Economics, 108(2), 349-366.

Securities Commission Malaysia (2020). Annual General Meeting Corporate Governance Checklist for Shareholders. Retrieved from http:www. maicsa.org.my/media/4980/technical_announcements_200206_2.pdf.

Slack, R., \& Shrives, P. (2010). Voluntary disclosure narratives: More research or time to reflect? Journal of Applied Accounting Research, 11(2),84-89.

The Malaysian Association of the Institute of Chartered Secretaries and Administrators. (2016). Best Practice Guide on AGMs for Listed Issuers.77-78. Retrieved from http://www.maicsa.org.my/ download/ publication/publication_agm.pdf.

Van der Elst, C. (2012). Shareholder rights and shareholder activism: The role of the general meeting of shareholders. Belgrade Law Review.

Vicknair, D., Hickman, K., \& Carnes, K. C. (1993). A note on audit committee independence: Evidence from the NYSE on "grey" area directors. Accounting Horizons, 7(1), 53. 
Wan-Hussin, W. N. (2009). The impact of family-firm structure and board composition on corporate transparency: Evidence based on segment disclosures in Malaysia. The International Journal of Accounting, 44(4), 313-333. 